\title{
Differences on allocation of available resources, in growth, reproduction, and survival, in an exotic gastropod of Physidae compared to an endemic one
}

\author{
Verónica Núñez
}

División Zoología Invertebrados, Museo de La Plata, Facultad de Ciencias Naturales y Museo, Universidad Nacional de La Plata, Paseo del Bosque s/n, 1900, La Plata, Argentina. (nmariaveronik@yahoo.com.ar)

\begin{abstract}
Physa acuta Draparnaud, 1805 is an invasive gastropod that can affect local species. In Argentina, it is widespread and abundant, even in environments inhabited by the native species Stenophysa marmorata Guilding, 1828. Its predominance raises the question whether this could be explained by a more successful energy allocation in functional requirements (growth, reproduction and survival) compared to S. marmorata. This study was aimed at comparing growth rates, as well as survival and fecundity, between both species under laboratory conditions. Individuals born on the same day were grouped in four per aquaria and kept under controlled conditions of food, light, and temperature. Snails were weekly measured (maximum shell length), and growth rates were calculated using the Von Bertalanffy's equation. The number of eggs and survivors were grouped by week. Stenophysa marmorata was larger at birth than Physa acuta and invested more energy in growth, delaying sexual maturity. This resulted in a disadvantage in fecundity and survival compared to $P$. acuta, which had a lower growth rate but matured earlier and survived longer. Furthermore, the growth of $P$. acuta was not affected by reproduction, its reproductive period was longer, consequently with more eggs laid than $S$. marmorata.
\end{abstract}

KEYWORDS. Fecundity, invasive species, longevity, Physa acuta, Stenophysa marmorata.

RESUMEN. Diferencias en la asignación de los recursos disponibles en crecimiento, reproducción y supervivencia entre un gasterópodo exótico y uno endémico de la familia Physidae. Physa acuta Draparnaud, 1805 es un gasterópodo invasor que puede afectar las poblaciones de especies locales. En Argentina, se encuentra ampliamente distribuida y en altas densidades, incluso en ambientes habitados por la especie nativa Stenophysa marmorata Guilding, 1828. Su predominancia podría ser explicada por un uso más exitoso de la energía en las demandas funcionales (crecimiento, reproducción y supervivencia) con respecto a $S$. marmorata. El objetivo de este trabajo fue comparar las constantes de crecimiento de ambas especies, teniendo en cuenta también los valores de supervivencia y fecundidad, en condiciones de laboratorio. Los individuos nacidos el mismo día fueron agrupados de a cuatro por acuario y mantenidos en condiciones controladas de alimentación, luz y temperatura. La longitud máxima de conchilla de los caracoles fue medida semanalmente, y la constante de crecimiento fue calculada usando la ecuación de Von Bertalanffy. El número de huevos y sobrevivientes era contado cada semana. Los ejemplares de $S$. marmorata nacieron con un tamaño mayor que los de Physa acuta e invirtieron más energía en el crecimiento, retardando su madurez sexual. Esto se tradujo en una desventaja en fecundidad y supervivencia con respecto a $P$. acuta, la cual presentó una constante de crecimiento menor pero maduró más tempranamente y sobrevivió más tiempo. Además, $P$. acuta no vio afectado su crecimiento por la reproducción y presentó un período reproductivo más prolongado, depositando así una mayor cantidad de huevos que $S$. marmorata.

PALABRAS CLAVES. Fecundidad, especie invasora, longevidad, Physa acuta, Stenophysa marmorata.

Invasive species are recognized globally as a major threat to biodiversity and ecosystem health (CARLTON \& Geller, 1993; StRAYer, 1999; RAHEL, 2002; LydeARD et al., 2004; Pimentel et al., 2005), often being able to produce irreversible changes in ecosystems, leading to declines and extinctions of native species (MACK et al., 2000). Furthermore, introduction of exotic species, especially gastropods, represent opportunities for significant changes in transmission dynamics and spread of infections because many species, may be intermediate hosts for waterborne parasites (MALEK, 1980; LEVY, 2004).

Physa acuta Draparnaud, 1805 is an invasive species, may be originated in North America, able to disperse rapidly and colonise new areas, particularly disturbed environments, and attains high densities (Winterbourn, 1980; Brackenbury \& ApPleton, 1993). This is a global concern as $P$. acuta has become invasive on four continents (APPLETON, 2003) and it have been reports of impacts on local species in South Africa, New Zealand and Australia (WINTERBOURN, 1980; BRACKENBURY \& APPLETON, 1993; ZuKOWSKI \& WALKER, 2009).
In Argentina, $P$. acuta is mentioned since the seventy decade (Paraense, 2005) and nowadays it is widespread and abundant, fundamentally in environments related to Del Plata basin, where the native species Stenophysa marmorata Guilding, 1828 inhabits.

Its predominant presence raises the question if this could be explained by a more successful allocation response partitioning of the time-energy resources available in functional demands (growth, reproduction and survival) compared to $S$. marmorata. These demands are not static and can vary in response to inherent characteristics, abiotic environmental factors and biotic factors such as predation, competition, and parasitism (Doughty \& Shine, 1998; Doums et al., 1998). The interplay among internal factors, external variables and allocation responses has a critical role in shaping the life history of an organism (CHASE, 1999). Age-specific body size and hence growth rates can reflect the partitioning of the time-energy resources available to an individual into growth, maintenance, storage, and reproduction.

The purpose of this study was to compare growth 
rates, considering also survival and fecundity, between both species under laboratory conditions; taking into account that estimation of demographic rates is not only of interest to life-history theory and population ecology, but can also be important for successful conservation of native species and management of exotic ones (FrICK et al., 2010).

\section{MATERIAL AND METHODS}

Eleven adults of Stenophysa marmorata and 15 of Physa acuta were collected in March of 2006 using sieves (15 cm diameter, $1.4 \mathrm{~mm}$ mesh size). Stenophysa marmorata was collected from Atalaya beach, in areas of alluvial plain of the Río de La Plata river $\left(35^{\circ} 02^{\prime} \mathrm{S}\right.$; $57^{\circ} 32^{\prime} \mathrm{W}$ ) and P. acuta from an artificial pond (at Saavedra

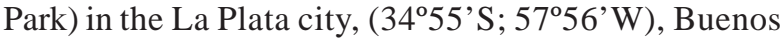
Aires province, Argentina. In the laboratory, ovipositions laid by these snails during the first month after collecting were used for the analysis. Of these eggs, 202 individuals of $S$. marmorata and 208 of $P$. acuta were born, which were observed until their death.

Individuals born at same day were separate in aquaria of $40 \mathrm{ml}$ (four individuals by recipient maximum). Snails were kept in running water without chlorine, at $24^{\circ} \mathrm{C}$ and controlated photoperiod ( $12 \mathrm{~h}$ light, $12 \mathrm{~h}$ dark) and they were fed ad libitum with lettuce leaves. Snails were weekly measured (maximum length of shell) using a binocular stereoscopic microscope with a micrometric ocular. Average and standard deviation (SD) of length by week were calculated. Growth analysis was made using Von BERTALANFFY's model (1938), which has been widely applied for gastropods (LOREAU \& BALUKU, 1987; ITUARTE, 1989, 1994; RuMi et al., 2007; GUTIÉRREZ-GREGORIC et al., 2010). This model is described by the equation $L_{t}=L_{\infty}(1$ $-e^{-k t}$ ) (where: $L t=$ shell length at time $t, L_{\infty}=$ maximum calculated (theoretic) shell length and $k=$ growth constant). In order to obtain an estimate of $L \propto$ WALFORD's method (1946) was employed, which consists on calculating the lineal relation between $L_{t+1}$ and $L_{t}$, being $L \infty$ the point where $L_{t+1}=L_{t}$, using only data with $\mathrm{N}>1$. Time was calculated according with the equation $t=[(\mathrm{m}$ - 1) $30+d] / 360$ (where $m=$ month and $d=$ day), then 1 week $=7 / 360$. The Wilcoxon test was used to test the goodness of fit between observed and expected data of lengths, because data did not show a normal distribution (ZAR, 1996).

The number of survivors and eggs were grouped by week, and percentage of the initial number of snails surviving at each week was calculated $\left(\% N_{0}\right)$. Mortality rate $\left(q_{x}\right)$ was calculated as $\left(N_{(x+1)}-N_{x}\right) / N_{x}$, being $N_{x}$ the number of snails at week $x$ and $N_{(x+1)}$ number of surviving snails at next week. Length correlations with $q_{x}$, oviposition size (number of eggs per oviposition) and number of eggs per $\% N_{0}$ were evaluated using Spearman coefficient (SC) (ZAR, 1996).

\section{RESULTS}

Specimens of S. marmorata were born with a mean length of $0.97 \mathrm{~mm}(\mathrm{SD} \pm 0.1)$ and only survived 60 weeks reaching a mean length of $7.56 \mathrm{~mm}$ in the last week. The maximum observed length in this species was $9.7 \mathrm{~mm}$, while calculated $L \infty$ was $8.72 \mathrm{~mm}$. This species began to lays eggs in the week 26 (near 6 months), with a mean size to that age of $6.6 \mathrm{~mm}$ (Fig. 1). Only the $37.13 \%$ of $N_{0}$ (202) reached this age. Stenophysa marmorata showed two reproductive efforts, the first among weeks 26 and 43, and the second shorter, among weeks 46 and 59, but with higher values of eggs per individual (with averages of 2.8 and 10.5 respectively).

Physa acuta was born with a mean length of 0.74 $\mathrm{mm}(\mathrm{SD} \pm 0.06)$ and it survived 88 weeks, reaching a mean length of $9.08 \mathrm{~mm}$. In this species calculated $L \infty$ was $11.87 \mathrm{~mm}$, while its maximum observed length was 10.24 $\mathrm{mm}$. Physa acuta began to oviposit in the week 13 with a mean size observed to that age of $3.63 \mathrm{~mm}$ (Fig. 2). The $49.52 \%$ of $N_{0}(208)$ reached this age. This species showed a continuous reproductive period untill week 77 , and then it was registered an oviposition of one non-viable egg.

Until week 26 Stenophysa marmorata grew more pronouncedly than Physa acuta, with a major slope, but from week 27 its growth declined, while $P$. acuta continued growing (Figs 1, 2). To that age (week 26) the onset of sexual maturity of $S$. marmorata occurred, while the beginning of the reproductive period in P. acuta (week 13) did not affect its growth. Length data of $S$. marmorata showed a depression between weeks 40 and 45 , coinciding with an increase in the mortality rate (Fig. 1) that evidently affected to specimens of more size, causing a descent in mean length.

Length presented a negative correlation with $q_{x}$ in

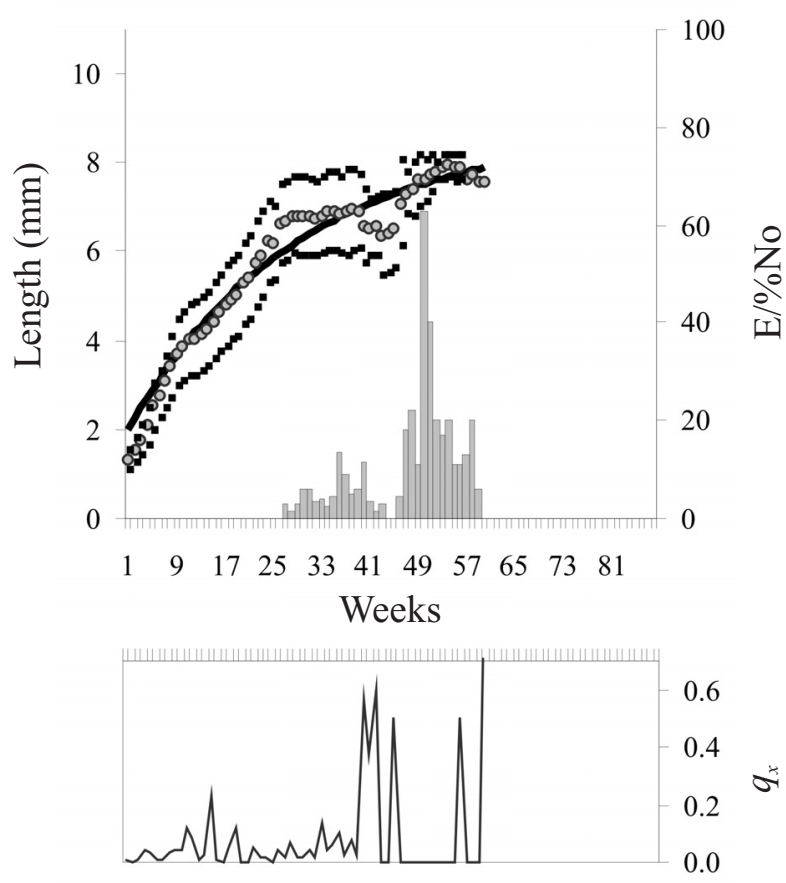

Figure 1. Theoretical length growth curve of Stenophysa marmorata Guilding, 1828 (black line); mean observed length by week (circles); mean observed length $\pm \mathrm{SD}$ (dots); number of eggs laid by the survivors proportion of the initial number of snails (E/ $\left.\% N_{0}\right)$ (bars); and mortality rate by week $\left(q_{x}\right)$ (gray line). 
P. acuta ( $\mathrm{SC}=-0.325, \mathrm{p}=0.002$ ), while this was not observed in S.marmorata. In both species, the average size of the oviposition increase with size of snails (Figs 3, 4), but ovipositions of $P$. acuta were bigger than in $S$. marmorata. The number of eggs per $\% N_{0}$ increased with the snails growth in both species, being evidenced a significant correlation, bigger in $S$. marmorata than in $P$. acuta $(\mathrm{SC}=0.697$ and $\mathrm{SC}=0.515$ respectively, with $\mathrm{p}<$ 0.0001 in both).

The growth model fitted well for both species $(S$. marmorata: $\mathrm{Z}=-0,832, \mathrm{p}=0,405$, for $\mathrm{N}=60$; while in $P$. acuta: $\mathrm{Z}=0,312, \mathrm{p}=0,755$, for 88 pair of data). Stenophysa marmorata showed a higher growth constant than $P$. acuta $(\mathrm{k}=1.82$ and 0.85 respectively). Consequently, growth rate equations for species are as follows: Stenophysa marmorata: $\mathrm{Lt}=8.72 \mathrm{~mm}\left(1-\mathrm{e}^{(-1.82 \mathrm{t})}\right)$ and Physa acuta: $\mathrm{Lt}=11.87 \mathrm{~mm}\left(1-\mathrm{e}^{(-0.85 \mathrm{t})}\right)$.

According to these equations Stenophysa marmorata overcame the $50 \%$ of its $L \infty$ in week 15 and it began to oviposit when overcame the $75 \%$ of its $L_{\infty}$. On the other hand P. acuta did not overcome the 50\% of its $L_{\infty}$ until week 40 and it began to oviposit with barely $30.5 \%$ of its $L \infty$ This species overcame the $75 \%$ of its $L_{\infty}$ when reaching the postreprodutive period in week 78 .

When plotting percentage of $L \infty$ of each species at the moments of birth, first oviposition and death, it is evidenced that, although $S$. marmorata showed a more marked slope when considering the total growth, P. acuta presented a bigger slope in the reproductive period (Fig. $5)$.
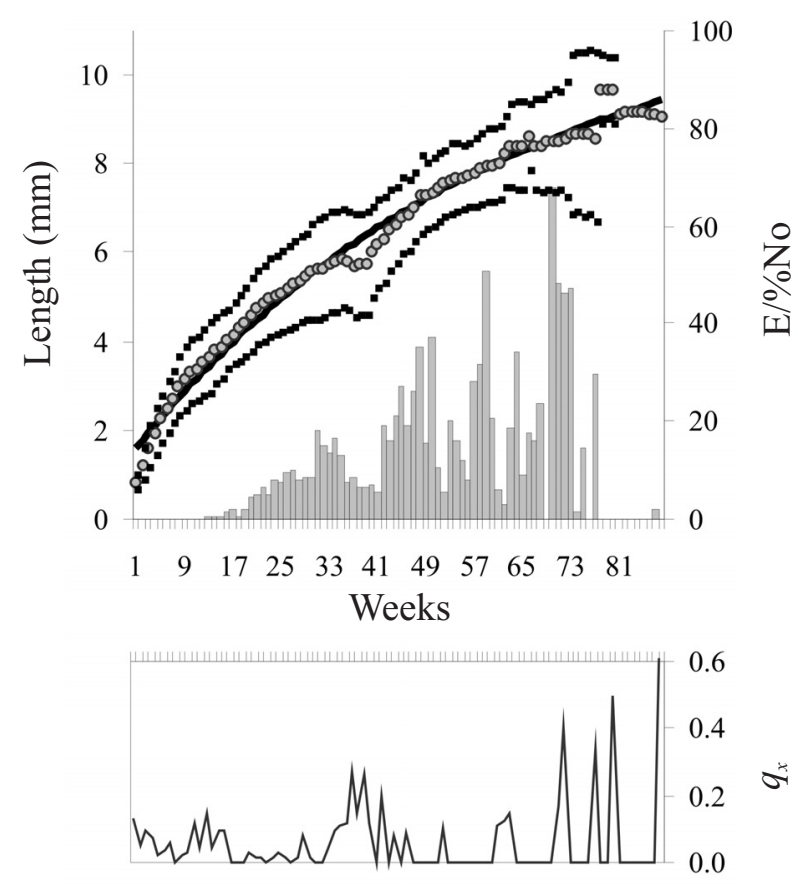

Figure 2. Theoretical length growth curve of Physa acuta Draparnaud, 1805 (black line); mean observed length by week (circles); mean observed length $\pm \mathrm{SD}$ (dots); number of eggs laid by the survivors proportion of the initial number of snails (E/\% $\left.N_{0}\right)$ (bars); and mortality rate by week $\left(q_{x}\right)$ (gray line).

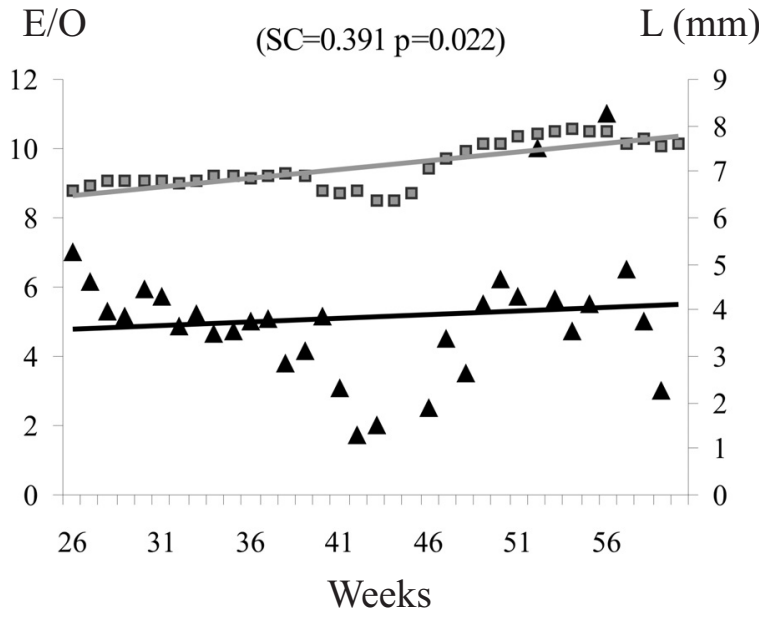

Figure 3. Weekly average of number of eggs per oviposition (E/O, black triangles) and length (L, grey squares) and its respective tendency lines in Stenophysa marmorata Guilding, 1828 during reproductive period (SC, value of Spearman coefficient between these two variables; $p$, probability).

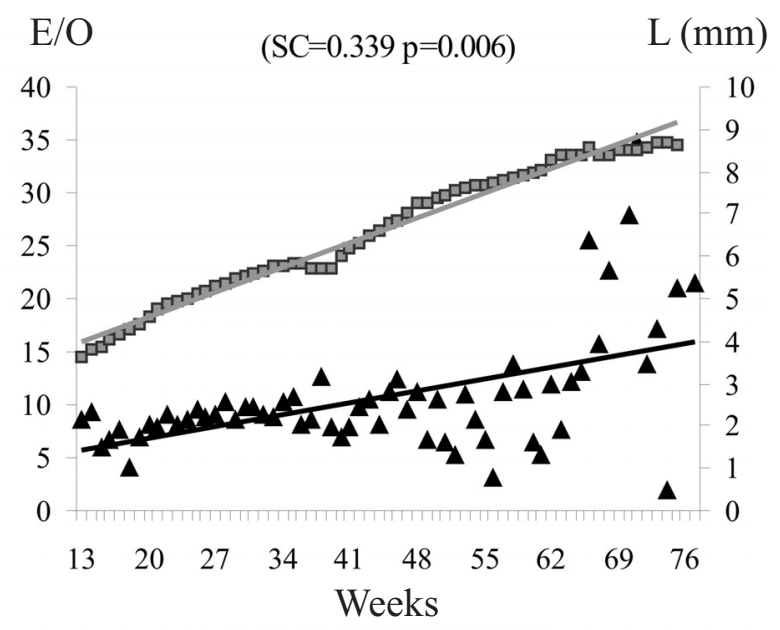

Figure 4. Weekly average of number of eggs per oviposition (E/O, black triangles) and length (L, grey squares) and its respective tendency lines in Physa acuta Draparnaud, 1805 during reproductive period (SC, value of Spearman coefficient between these two variables; $\mathrm{p}$, probability).

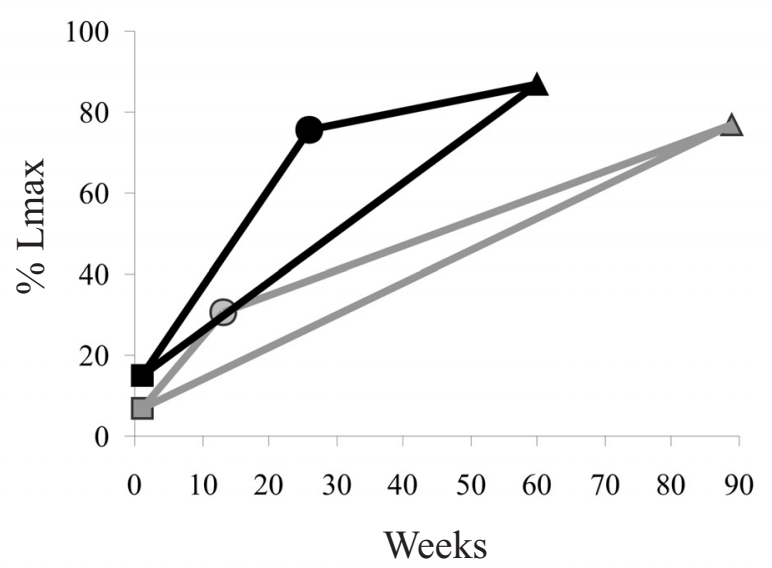

Figure 5. Percentage of the maximum calculated length $\left(\% L_{m a x}\right)$ that individuals of Stenophysa marmorata Guilding, 1828 (black) and Physa acuta Draparnaud, 1805 (gray) registered when being born (squares), to begin reproduction period (circles) and to die (triangles). 


\section{DISCUSSION}

Both of these snails suffered a high mortality during the first weeks; as in others gastropods like Biomphalaria peregrina (d'Orbigny, 1835) under laboratory conditions (RUMI, 1993). According to MARTín (2001) Physella venustula (Gould, 1848) also has a higher mortality at first ages (up to $3.5 \mathrm{~mm}$ ) and then decrease, so that the $95 \%$ dies at pre-reproductive period under natural conditions. Furthermore, in P. acuta mortality rate decreases with the growth in length (shown in a negative correlation between both variables), so that the most susceptible individuals are the smallest. These variables showed no correlation in S. marmorata, so that the susceptibility of this species does not appear to be linked to size. Less than $40 \%$ of individuals of $S$. marmorata reached sexual maturity, while almost the $50 \%$ of $P$. acuta did it. The mean size observed in S. marmorata, at the beginning of the reproductive period almost double the one shown by $P$. acuta, but in this last species the prereproductive period lapses in half of the time that in $S$. marmorata. According to THOMAs \& Mc CLINTOCк (1990), the length of the pre-reproductive period and the size of the specimens to the beginning of the reproductive period depends on the temperature, however in this case the temperature conditions was the same for both species. Furthermore, $P$. acuta had a more lingering reproductive period (twice as much) and consequently it laid more eggs than S. marmorata.

Growth of both species fitted with Von Bertalanffy model, and $S$. marmorata presented a higher growth rate than P. acuta. The growth rate of many freshwater gastropods is related with the temperature and the feeding (De WitT, 1955; Russel-Hunter, 1961; among other), furthermore, temperature is an indirect factor of the oviposition because growth rate and the development to reach sexual maturity depends of it. However, the differences observed here in growth rate and time of sexual maturity of $S$. marmorata and P. acuta cannot be attributed to these factors.

When break down the increments of longitude in the pre-reproductive and reproductive periods it is evidenced that in both species the biggest growth occurs previous to the sexual maturation. However, the decrease in the intensity of growth after sexual maturity is much more pronounced in S. marmorata, which shows that the energy assigned to the reproduction affects its growth to a greater extent than in $P$. acuta.

Both species barely reached $78 \%$ of the lengths observed in field (TAYLOR, 2003), maybe because of a deficient diet or stress. These differences could be also explained by the size of recipients compared to natural environments, since size of Physidae's individuals, maintained in equal conditions, is proportional to the volume of water that it contains them (Aguayo, 1938). Independently of the reason, this affected equally to both species since they were kept under the same conditions, allowing a comparison of its populational parameters.

The existence of a positive correlation between the size of the ovipositions and that of the specimens that laid them observed in both species was already proved in Physa fontinalis (Linneaus, 1758) under natural conditions (DE WITT, 1955). However, the same species shows a progressive decline in the number of egg per oviposition as the snail becomes older under artificial conditions (DunCAN, 1959). A similar decrease in egg production has been reported in Physa gyrina (Say, 1821), under artificial conditions, and another many species of Basommatophora listed by DE WITT (1954). In this case, the artificial conditions did not affected the eggs production and the two species shown an increase in number of eggs and in size of ovipositions with length growth. This implies that, in both species, the largest specimens of reproductive period contribute more to the next generation in offspring. Specimens of that size are the lesser affected by mortality in $P$. acuta, according to estimated correlation above.

Stenophysa marmorata was born with a bigger size to the one observed in Physa acuta and invested more energy in growth delaying its sexual maturity. This resulted in a fecundity and survival disadvantage compared to $P$. acuta which presented a lesser growth rate but it matured earlier and survived longer. Furthermore, growth of $P$. acuta was not affected by reproduction as in $S$. marmortata.

Acknowledgments. To Diego Gutiérrez Gregoric, Noelia Ferrando and Julieta Sánchez for their assistance in the laboratory. To Alejandra Rumi for comments on the manuscript. To CONICET (PIP $N^{\circ}$ 2711) and Facultad de Ciencias Naturales y Museo, UNLP (PN: 470) for the financial support.

\section{REFERENCES}

Aguayo, C. G. 1938. Los moluscos fluviátiles Cubanos. Memorias de la Sociedad Cubana de Historia Natural 12:203-242, 253-276.

Appleton, C. C. 2003. Alien and invasive fresh water Gastropoda in South Africa. African Journal of Aquatic Science 28:69-81.

Brackenbury, T. D. \& Appleton, C. C. 1993. Recolonization of the Umsindusi River, Natal, South Africa, by the invasive gastropod, Physa acuta (Basommatophora, Physidae). Journal of Medical and Applied Malacology 5:39-44.

Carlton, J. T. \& Geller, J. B. 1993. Ecological roulette: The global transport of nonindigenous marine organisms. Science 261:78-82.

Chase, J. M. 1999. To grow or to reproduce? The role of lifehistory plasticity in food web dynamics. The American Naturalist 154:571-586.

De WitT, R. M. 1954. Reproductive capacity in a pulmonate snail (Physa gyrina Say). The American Naturalist 88:59-164. 1955. The ecology and life history of the pond snail Physa gyrina. Ecology 36:40-44.

Doughty, P. \& Shine, R. 1998. Reproductive energy allocation and long-term energy stores in a viviparous lizard (Eulamprus tympanum). Ecology 79:1073-1083.

Doums, C.; Perdieu, M. \& Jarne, P. 1998. Resource allocation and stressful conditions in the aphallic snail Bulinus truncatus. Ecology 79:720-733.

Duncan, C. J. 1959. The life cycle and ecology of the freshwater snail Physa fortinalis (L.). Journal of Animal Ecology 28:97-117.

Frick, W. F.; Reynolds, D. S. \& Kunz, T. H. 2010. Influence of climate and reproductive timing on demography of little brown myotis Myotis lucifugus. Journal of Animal Ecology 79:128136

GutiérRez-Gregoric, D. E.; NúÑEZ, V. \& Rumi, A. 2010. Population studies of an endemic gastropod from waterfall environments. American Malacological Bulletin 28:159-165.

ItUARTE, C. F. 1989. Growth dynamics in a natural population of Biomphalaria straminea (Dunker, 1848) from Bella Union, 
Artigas, Uruguay. Studies Neotropical Fauna and Environment 24:35-40.

1994. Temporal variation in age structure of a natural population of Biomphalaria tenagophila (Gastropoda: Planorbidae) from a rice field irrigation channel system at Artigas, Uruguay. Malacological Review 27:13-21.

Levy, K. 2004. Neglected consequences: role of introduced aquatic species in the spread of infectious diseases. EcoHealth 1:296305.

Loreau, M. \& Baluku, L. 1987. Growth and demography of populations of Biomphalaria pfeifferi (Gastropoda, Planorbidae) in the laboratory. Journal of Molluscan Studies 53:171-177.

Lydeard, C.; Cowie, R. H.; Ponder, W. F.; Bogen, A. E.; Bouchet, P.; Clark, S. A.; Cummings, K. S.; Frest, T. J.; Gargominy, O.; Herbert, D. G.; Hershler, R.; Perez, K. E.; Roth, B.; Seddon, M.; Strong, E. E. \& Thompson, F. G. 2004. The global decline of nonmarine mollusks. BioScience 54:321-330.

Mack, R. N.; Simberloff, D.; Lonsdale, W. M.; Evans, H.; Clout, M. \& BAzZAZ, F. 2000. Biotic invasions: causes, epidemiology, global consequences, and control. Ecological Applications 10:689-710.

MaleK, E. A. 1980. Snail-Transmitted Parasitic Diseases. Boca Raton, CRC. v.2, 170p.

Martín, P. R. 2001. Life cycle and production of the exotic snail Physa venustula (Pulmonata: Physidae) in the Napostá Grande stream, southern pampas, Argentina. Journal of Freshwater Ecology 16:93-104.

Paraense, W. L. 2005. Planorbidae, Lymnaeidae and Physidae of Argentina (Mollusca: Basommatophora). Memórias do Instituto Oswaldo Cruz 100(5):491-493.

Pimentel, D.; Zuniga, R. \& Morrison, D. 2005. Update on the environmental and economic costs associated with alieninvasive species in the United States. Ecological Economics 52:273-288.

Rahel, F. J. 2002. Homogenization of freshwater faunas. Annual Review of Ecology and Systematics 33:291-315.
Rumi, A. 1993. Radular variability and life tables of two morphs of Biomphalaria peregrina (Pulmonata, Planorbidae). Journal of Medical and Applied Malacology 5:21-30.

Rumi, A.; Gutierrez Gregoric, D. E. \& Roche, M. A. 2007. Growth rates fitting using the von Bertalanffy model: an analysis in natural populations of Drepanotrema spp. (Gastropoda: Planorbidae). Revista de Biología Tropical 55:559-567.

Russell-Hunter, W. 1961. Annual variations in growth and density in natural populations of freshwater snails in the west of Scotland. Proceedings of the Zoological Society of London 136:219-253.

Strayer, D. L. 1999. Effects of alien species on freshwater mollusks in North America. Journal of the North American Benthological Society 18:74-98.

TAYLOR, D. W. 2003. Introduction to Physidae: biogeography, classification, morphology. Revista de Biología Tropical 51(Suppl. 1):1-287.

Thomas, D. L. \& Mc Clintock, J. B. 1990. Embryogenesis and the effects of temperature on embryonic developmente, juvenile growth rates, and the onset of oviposition in the fresh-water pulmonate gastropod Physella cubensis. Invertebrate Reproduction and Development 17(1):65-71.

Von Bertalanffy, L. 1938. A quantitative theory of organic growth. Human Biology 10(2):181-213.

WALFORD, L. A. 1946. A new graphic method of describing the growth of animals. Biological Bulletin 90:141-147.

Winterbourn, M. J. 1980. The distribution and biology of the freshwater gastropods Physa and Physastra in New Zealand. Journal of the Malacological Society of Australia 4:233234.

ZAR, J. H. 1996. Biostatistical analysis. Upper Saddle River, Prentice-Hall. 662p.

Zukowski, S. \& Walker, K. F. 2009. Freshwater snails in competition: alien Physa acuta (Physidae) and native Glyptophysa gibbosa (Planorbidae) in the River Murray, South Australia. Marine and Freshwater Research 60:9991005 .

Recebido em maio de 2010. Aceito em outubro de 2010. ISSN 0073-4721

Artigo disponível em: www.scielo.br/isz 